\title{
An unusual intradural involvement secondary to Burkitt's lymphoma
}

\author{
Valentina Paolucci, ${ }^{1}$ Claudia Rendeli, ${ }^{1}$ Libero Lauriola, ${ }^{2}$ Mariangela Novello ${ }^{2}$ \\ ${ }^{1}$ Department of Paediatric Science, Catholic University, Rome, Italy; \\ 2Department of Pathology, Catholic University, Rome, Italy
}

Correspondence to Professor Claudia Rendeli c.rendeli@libero.it

\section{DESCRIPTION}

A 6-year-old boy started feeling oral pain during daily hygienic procedures and pain localised on the neck, with consequent right deviation of the head. Six months later, an ultrasound examianation of the neck was performed, leading to the misdiagnosis of retro-mandibular abscess, treated with antibiotic therapy with temporary improvement. After a week, he deteriorated developing a typical
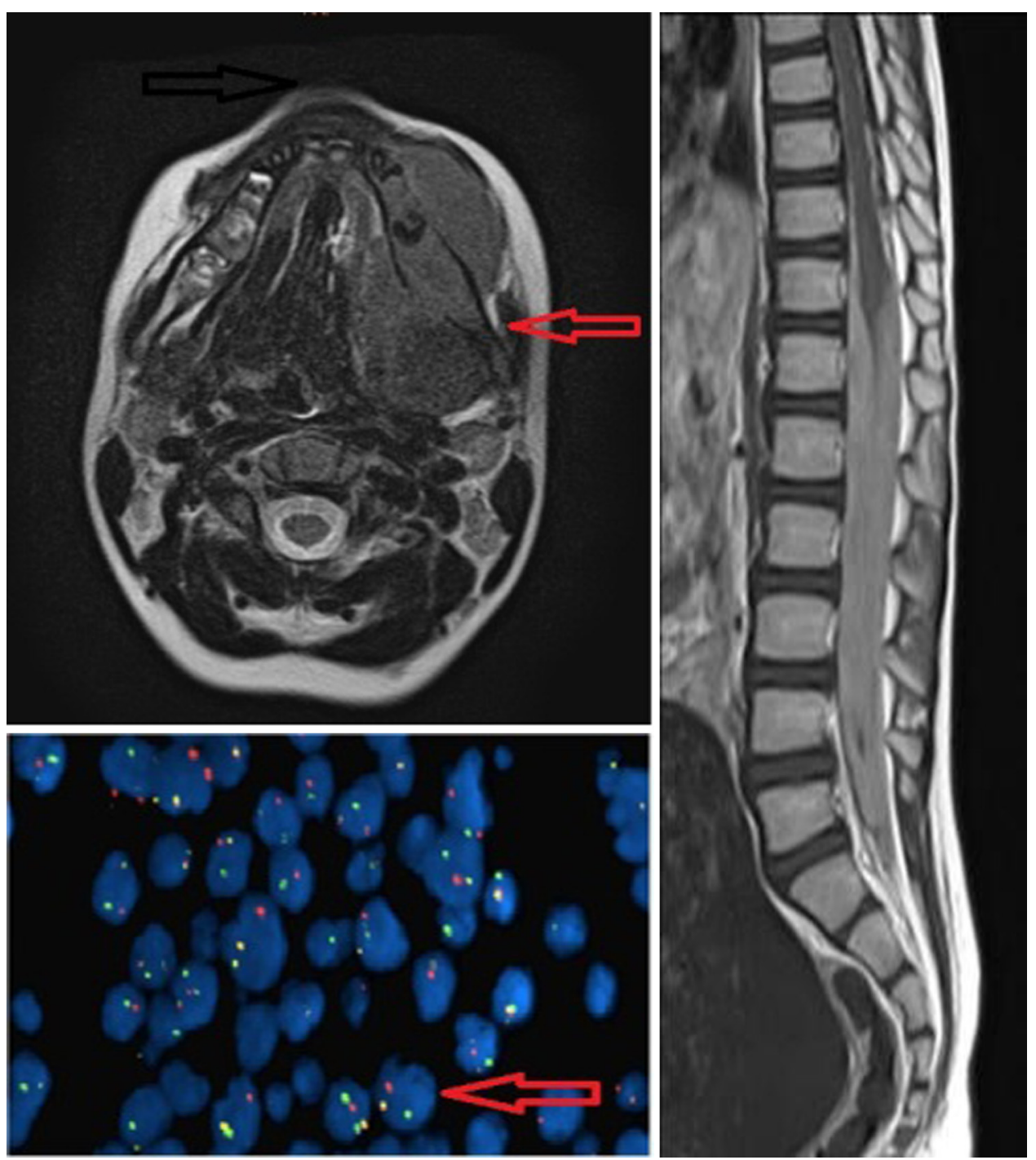

Figure 1 (A) MRI preoperative sagittal contrast-enhanced T1-weighted image of head showing mandibular and iuxta mandibular swelling with muscles infiltration. (B) MRI preoperative sagittal contrast-enhanced T1-weighted image of spine showing the subarachnoid space filled by intensely contrast-enhancing intradural tissue encasing conus medullaris. (C) Fluorescent insitu hybridisation for C-MYC, the arrow shows one allele with localisation of both probes (red and green) and one allele with segregation of both probes (yellow). 


\section{BMJ Case Reports}

cauda equina syndrome,${ }^{1}$ characterised by sphincter disturbances, frequent falls and progressive paraplegia. Therefore head and spinal MRI were performed and the examination showed mandibular and iuxta-mandibular swelling with muscles infiltration (figure 1A), diffuse involvement of subarachnoid space filled by intensely contrast-enhancing intradural tissue encasing conus medullaris between D12S1(figure 1B), and cervical swelling with a nodule in C5. On the same day, the child was transferred to our hospital and underwent surgical decompression with laminotomy between D12-S1 and laminectomy S1 that showed an extensive intradural involvement of cauda's roots that appeared swollen and reddish. Histological examination of film biopsy and fluorescent insitu hybridisation (figure 1C) were performed, and showed a rare intradural involvement of the cauda secondary to Burkitt's lymphoma. ${ }^{2}$ Therefore, the patient was started on steroid therapy and was admitted to the Paediatric Oncology Unit in good general condition and with partial recovery of spontaneous motility. To complete the diagnosis, osteo-medullar biopsy was performed, resulting negative. Some days after he performed a CT scan that showed right renal involvement and started intratecal chemotherapy treatment. ${ }^{3}$
Learning points

- Atypical presentation of Burkitt's lymphoma.

- Among intradural masses, Burkitt's lymphoma should be kept in mind.

- Steroid therapy and chemotherapy are first therapeutic approach.

Competing interests None.

Patient consent Obtained.

\section{REFERENCES}

1. Ziegler JL, Bluming AZ, Morrow RH, et al. Central nervous system involvement in Burkitt's lymphoma. Blood 1970;36:718-28.

2. Templeton AC. Changing pattern of residual tumor in Burkitt lymphoma: findings at autopsy. Arch Pathol Lab Med 1976;100:503-5.

3. Matsubara H, Watanabe K, Sakai H, et al. Rapid improvement of paraplegia caused by epidural involvements of Burkitt's lymphoma with chemotherapy. Spine 2004;29:E4-6.

This pdf has been created automatically from the final edited text and images.

Copyright 2012 BMJ Publishing Group. All rights reserved. For permission to reuse any of this content visit http://group.bmj.com/group/rights-licensing/permissions.

BMJ Case Report Fellows may re-use this article for personal use and teaching without any further permission.

Please cite this article as follows (you will need to access the article online to obtain the date of publication).

Paolucci V, Rendeli C, Lauriola L, Novello M. An unusual intradural involvement secondary to Burkitt's lymphoma. BMJ Case Reports 2012;10.1136/bcr.01.2012.5604, Published XXX

Become a Fellow of BMJ Case Reports today and you can:

- Submit as many cases as you like

- Enjoy fast sympathetic peer review and rapid publication of accepted articles

- Access all the published articles

- Re-use any of the published material for personal use and teaching without further permission

For information on Institutional Fellowships contact consortiasales@bmjgroup.com

Visit casereports.bmj.com for more articles like this and to become a Fellow

Keep up to date with all published cases by signing up for an alert (all we need is your email address) http://casereports.bmj.com/cgi/alerts/etoc 